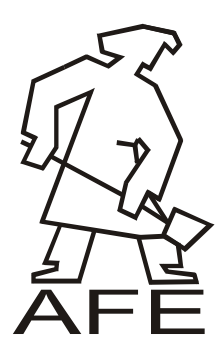

ARCHIVES

of

\title{
Heat Balance Analysis of EPS Products Shaping Process
}

\author{
R. Wladysiak ${ }^{a, *}$ W. Bogus ${ }^{\text {b }}$, T. Pacyniak ${ }^{\text {a }}$ \\ ${ }^{a}$ Department of Materials Engineering and Production Systems, Technical University of Lodz \\ 1/15 Stefanowskiego Street 90-924 Lodz, Poland \\ ${ }^{\mathrm{b}}$ SchaumaPlast Organika Sp. z o.o., 180/194 Dabrowskiego Street, 93-231 Lodz, Poland \\ *Corresponding author. E-mail address: ryszard.wladysiak@p.lodz.pl
}

Received 31.05.2013; accepted in revised form 04.06.2013

\begin{abstract}
The work is a part of research into the reduction of energy consumption in the production of EPSthrough the modernization of technological equipment used. This paper presents the results of research and analysis of heat transfer process between the water vapor that was provided to machine, the mold, the product and the environment. The paper shows the calculation of the heat balance of the production cycle for two types of mold: standard and modernized. The performance tests used an infrared imaging camera. The results were used to develop a computer image analysis and statistical analysis. This paper presents the main stages of the production process and the construction of technological equipment used, changing the mold surface temperature field during the production cycle and the structure of the heat balance for the mold and its instrumentation. It has been shown that the modernization of construction of technological equipment has reduced the temperature field and as a consequence of decreased of demand for process steam production cycle.
\end{abstract}

Keywords: Innovative technologies and materials, Heat balance, Steam, EPS, Thermography

\section{Introduction}

The ongoing work is a part of research on the modernization of the production process of expanded polystyrene (EPS) in the company SchaumaPlast Organika Sp. z o. o. in Lodz. The essence of the research is to reduce the energy consumption of the manufacturing process used for the modernization of technological equipment. The modular packaging and molded polystyrene is used EPS (styrofoam). Preparation of raw material for the production takes place through the pre-expansion, in which the balls EPS due to the heat affecting the blowing agent contained in polystyrene, increase their volume to the desired density. The next stage is seasoning in silos, in which the release occurs inside of pentane already porous EPS beads. The material prepared is injected into the mold, in which by means of steam is heated and then cooled. Thus bead material increase in volume, they combine with each other and match the shape of the mold cavity of product $[1,2]$.

The aim of the work was to analyze the process of heat transfer between steam brought to machine, the mold, the product and the environment and also the calculation of the heat balance of the production cycle for two types of equipment: standard and modernized one.

\section{Experimental}

Tests were conducted on a production station of machine made by a German company Kurtz $\mathrm{GmbH}$. The machine cycle consists of the following steps: closing the mold and filling material, steam entering, cooling and stabilization of the device, the deformation and removing product from the mold. In Figures 
1 and 2 adequately the scheme and the view of mold tooling in a production machine was shown of a typical EPS product that is shown in Figure 3.

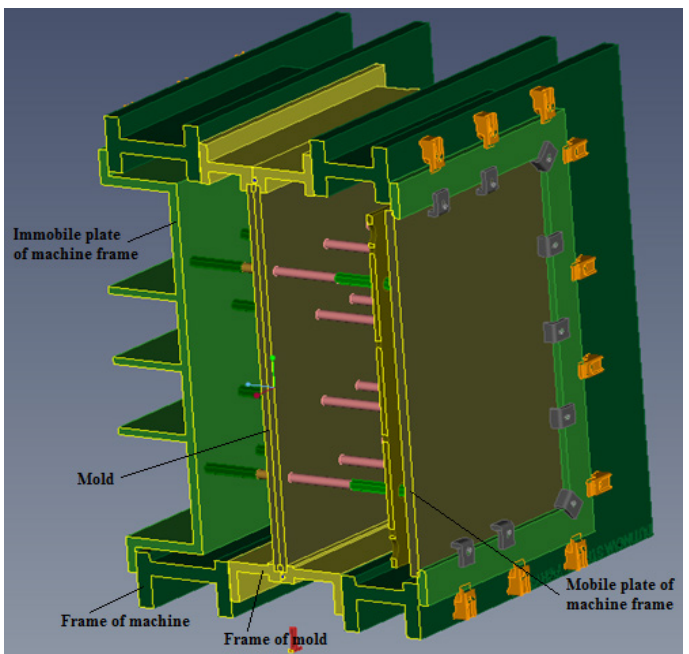

Fig. 1. Scheme of mold construction for manufacturing of EPS products

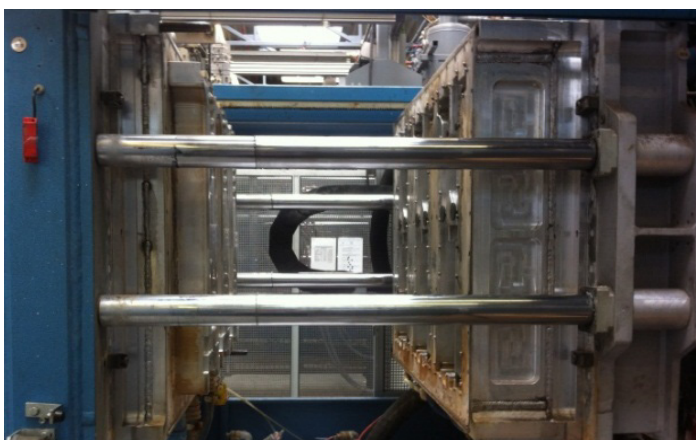

Fig. 2. Photo of mold equipment in manufacturing machine

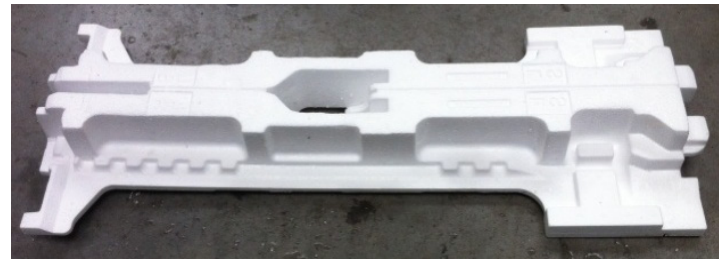

Fig. 3. Photo of EPS product

This instrumentation has a box-like structure formed by the fixed mold plate in the mold, respectively, which are installed in a immobile (Fig. 1, right side) and a movable (left) frame of the machine. Into the space existing between the plates is supplied with steam at $120 \div 130^{\circ} \mathrm{C}$ and a pressure of $0.22 \div 0.23 \mathrm{MPa}$. During the modernization of equipment the construction and the material of the immobile plate was changed from cast iron into aluminium and also the thermal insulation layer inside the aluminum frame of mold and the machine was used.

The heat balance calculation was used: - the first law of thermodynamics

$$
\mathrm{Q}=\mathrm{U}_{2}-\mathrm{U}_{1}=\mathrm{h}_{2}-\mathrm{h}_{1}+\mathrm{p}_{2} \mathrm{~V}_{2}-\mathrm{p}_{1} \mathrm{~V}_{1},
$$

where: $U_{1}, U_{2}$ - internal energy of the system, - $h_{1}, h_{2}$ enthalpy, $\mathrm{p}_{1}, \mathrm{p}_{2}, \mathrm{~V}_{1}, \mathrm{~V}_{2}$ - the pressure and volume of the system in states 1 and 2 ,

with the change of internal energy is equal to the change in kinetic energy of the molecules and is the model

$$
\Delta \mathrm{U}=\Delta \mathrm{E}_{\mathrm{k}}=\mathrm{m} \mathrm{c}_{\mathrm{w}} \Delta \mathrm{t},
$$

where: $m$-weight, $\mathrm{c}_{\mathrm{w}}$ - specific heat at constant volume,

$\Delta \mathrm{t}$ - change in temperature of the substance,

- Newton law determining the density of the heat flux exchanged between the surface of chilled and ambient:

$$
\mathrm{q}=\alpha\left(\mathrm{t}_{\text {pow }}-\mathrm{t}_{\mathrm{ot}}\right)
$$

where: $q_{\text {pow }}$ - the density of the heat flux exchanged between the cooled surface and the surroundings; $\alpha$ - coefficient of heat transfer; $t_{\text {pow }}-$ the temperature of the surface; $t_{\mathrm{ot}}-$ ambient temperature.

- Stefan-Boltzmann equation, which determines the amount of energy emitted by the formula:

$$
\mathrm{E}=\varepsilon \mathrm{C}_{0} \mathrm{~A} \mathrm{~T}^{4} \text {, }
$$

where: $C_{0}-$ Stefan-Boltzmann constant, $\varepsilon$ - surface emissivity of the substance, $\mathrm{T}-$ absolute temperature of the surface $[3,4]$.

\section{Results}

In Fig. 4-6 are examples of thermographic results of equipment molds respectively No. 1 and No. 2 in the process of making a styrofoam product.

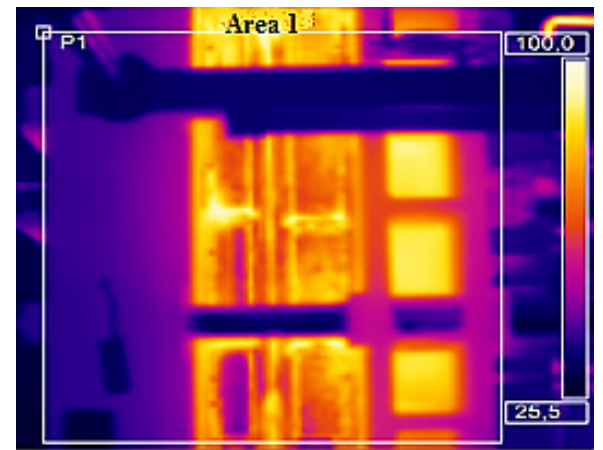

Fig. 4. Temperature field of mold equipment in manufacturing machine No. 1 - view from mold parting side

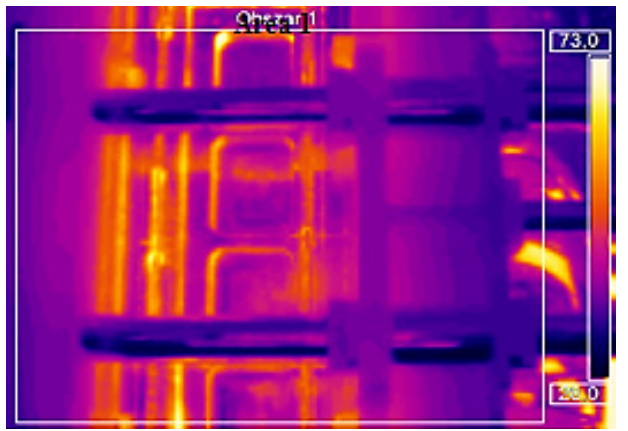

Fig. 5. Temperature field of mold equipment in manufacturing machine No. 2 - view from mold parting side 
a)

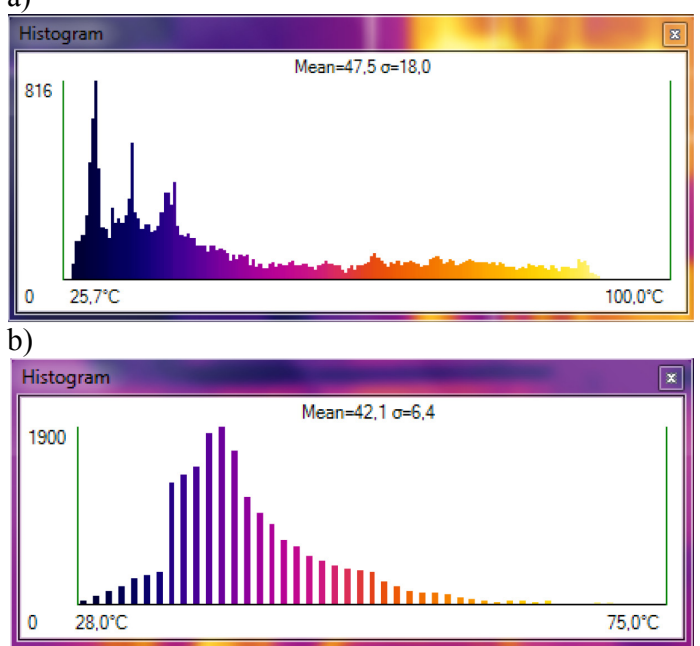

Fig. 6. Histogram of temperature field of area 1 of mold equipment in manufacturing machine:

a) No. 1 (Fig.4), b) No. 2 (Fig. 5)

The research shows that the area of instrumentation molds characterized by a temperature variation of $26 \div 100^{\circ} \mathrm{C}$ for machines No. 1 and the $28 \div 75^{\circ} \mathrm{C}$ for machine No. 2 , and the average value of the temperature distribution (Fig. 6), which was $47.5^{\circ} \mathrm{C}$ for mold equipment 1 and $42.1^{\circ} \mathrm{C}$ - for mold No. 2. The temperature field of the surface of the modernized mold tooling No. 2 characterized by a much higher stability, which confirms approximately 3-times reduction in standard deviation of the distribution of temperature fields examined form $\sigma=18.0$ to $\sigma=6.4$.

In addition, research shows that the highest range of temperature fields occurred in the framework and the immobile plate and movable mold tooling machines 1 . The instrumentation after upgrading has much lower temperature and its highest range is at the surface of the mold frame around the mold parting surface.

Na podstawie przeprowadzonych na stanowiskach produkcyjnych badań i analiz opracowano równanie bilansu energii cieplnej doprowadzonej za pomocą pary wodnej opisane wzorem:

$$
\mathrm{Q}_{\mathrm{d}}=\mathrm{Q}_{\mathrm{fo}}+\mathrm{Q}_{\mathrm{w}}+\mathrm{Q}_{\mathrm{ch}}+\mathrm{Q}_{\text {konw }}+\mathrm{Q}_{\text {prom }}+\mathrm{Q}_{\mathrm{k}}+\mathrm{Q}_{\mathrm{st}}
$$

where:

$Q_{d}$ - the heat supplied to the machine by means of technological steam,

$\mathrm{Q}_{\mathrm{w}}$ - heat received by the product material EPS during processing and removed together with the product,
$\mathrm{Q}_{\mathrm{fo}}$ - change of heat accumulated by the tooling mold resulting from cyclic temperature changes,

$\mathrm{Q}_{\mathrm{ch}}$ - heat received from the mold by cooling water spray,

$\mathrm{Q}_{\mathrm{konw}}$ - heat absorbed by the surroundings due to convection,

$\mathrm{Q}_{\text {prom }}$ - heat radiated by the mold tooling environment,

$\mathrm{Q}_{\mathrm{k}}$ - heat discharged from the condensate - water resulting from the cooled steam for instrumentation,

$\mathrm{Q}_{\mathrm{st}}$ - loss of steam caused by such stabilization of the vacuum, venting and leakage mold.

Table 1 shows the values of physical constants and the values of the parameters used to calculate the components of heat consumed in the researched process of the molds equipment of machine No. 1 and No. 2. Quantity of steam was based on heat meter installed at the inlet steam to the plant. Enthalpy and specific volume of water vapor was determined on the basis of the graph of enthalpy - entropy [5]. Analysis of product design and tooling provided data on the mass and geometry of its components. The values of temperature of the components involved in the heat exchange of water vapor with the surrounding equipment specified on the basis of statistical analysis of variability in time of the production cycle instrumentation temperature fields examined using an infrared camera.

Table 2 shows the calculation formulas developed on the basis of knowledge of the subject of study for components of the heat balance [4-6].

The developed models includes among others cyclic heat consumption for raising the temperature cooled-tooling components freely and forcibly cooled in a shower of water (Tab. 2, No. 2, 4 and 6) and a blowing agent in the evaporation heat-formed article. In addition, it's developed a model to calculate the heat demand during the start-up of steam production machine $\left(\mathrm{Q}_{\text {rozr }}\right.$, Table 2: No. 9), which are consumed every day as planned working time in the company.

Table 3 shows the results of components calculations of the balance of heat energy supplied to the machine in the form of technological steam by the formulas shown in Tab. 2. These results are shown in Fig. 7 as a plot of the percentage calculated balance components charged to the heat delivered to the machine $\mathrm{Q}_{\mathrm{d}}$ at the time of the production cycle.

Presented in Tab. 3 the summary of research results shows that modernization of mold equipment in the machine No. 2 decreases from $6943.6 \mathrm{~kJ}$ to $5552.1 \mathrm{~kJ}$ or about $20 \%$ of the demand for heat which is supplied to the machine during the manufacturing cycle of products. In addition, calculations show that the heat energy lost during machine startup is about four times the demand for heat during the manufacturing cycle. 
Table 1.

Values of physical constants and calculation parameters for researched mold equipment

\begin{tabular}{|c|c|c|c|c|}
\hline & Constant or parameter name, symbol & Unit & Machine No. 1 & Machine No. 2 \\
\hline 1 & Consumption steam in production cycle, $\mathrm{m}_{\mathrm{z}}$ & $\mathrm{kg}$ & 2.495 & 1.995 \\
\hline 2 & Entalphy of steam, h & $\mathrm{kJ} / \mathrm{kg}$ & 2720 & 2720 \\
\hline 3 & Pressure of delivered steam, $\mathrm{p}_{2}$ & $\mathrm{MPa}$ & 0.09 & 0.09 \\
\hline 4 & Specific volume, $\mathrm{V}_{1}$ & $\mathrm{~m}^{3} / \mathrm{kg}$ & 0.7 & 0.7 \\
\hline 5 & Specific heat of water, $c_{w}$ & $\mathrm{~kJ} /(\mathrm{kgK})$ & 4.19 & 4.19 \\
\hline 6 & Specific heat of product material, $\mathrm{c}_{\mathrm{ps}}$ & $\mathrm{kJ} /(\mathrm{kgK})$ & 1.5 & 1.5 \\
\hline 7 & Heat of vaporization of blowing agent, $c_{\text {par-porof }}$ & $\mathrm{kJ} / \mathrm{kg}$ & 336.27 & 336.27 \\
\hline 8 & Specific heat of frame material $(\mathrm{Al}), \mathrm{c}_{\mathrm{f}}=\mathrm{c}_{\mathrm{rf}}=\mathrm{c}_{\mathrm{rm}}=\mathrm{c}_{\mathrm{prmr}}$ & $\mathrm{kJ} /(\mathrm{kg} \mathrm{K})$ & 0.91 & 0.91 \\
\hline 9 & Specific heat of plate material, $c_{\text {prms }}=c_{\mathrm{Zl}}$ lub $c_{\mathrm{Al}}$ & $\mathrm{kJ} /(\mathrm{kg} \mathrm{K})$ & 0.48 & 0.91 \\
\hline 10 & Heat transfer coefficient, $\alpha$ & $\mathrm{W} /\left(\mathrm{m}^{2} \mathrm{~K}\right)$ & 30 & 30 \\
\hline 11 & Stefan - Boltzmann constant, $\mathrm{C}_{0}$ & $\mathrm{~W} /\left(\mathrm{m}^{2} \cdot \mathrm{K}^{4}\right)$ & $5.67 \mathrm{E}-08$ & $5.67 \mathrm{E}-08$ \\
\hline 12 & Emissivity of elements surface $\mathrm{Al}, \varepsilon_{\mathrm{Al}}$ & & 0.65 & 0.65 \\
\hline 13 & Emissivity of machine surface, $\varepsilon_{\mathrm{m}}$ & & 0.95 & 0.95 \\
\hline 14 & Product weight, $\mathrm{m}_{\mathrm{w}}$ & $\mathrm{kg}$ & 0.59 & 0.46 \\
\hline 15 & Mass of steam condensate received from the mold, $\mathrm{m}_{\mathrm{k}}$ & $\mathrm{kg}$ & 0.75 & 0.75 \\
\hline 16 & Mass of steam condensate in product, $\mathrm{m}_{\mathrm{wps}}$ & $\mathrm{kg}$ & 0.018 & 0.016 \\
\hline 17 & Mass of mobile and im mobile part of mold, $\mathrm{m}_{\mathrm{fr}}+\mathrm{m}_{\mathrm{fs}}$ & $\mathrm{kg}$ & 131 & 131 \\
\hline 18 & Mold frame weight, $\mathrm{m}_{\mathrm{rfs}}+\mathrm{m}_{\mathrm{rfr}}$ & $\mathrm{kg}$ & 101 & 101 \\
\hline 19 & Machine frame weight, $\mathrm{m}_{\mathrm{rms}}+\mathrm{m}_{\mathrm{rmr}}$ & $\mathrm{kg}$ & 106 & 106 \\
\hline 20 & Machine immobile plate weight, $\mathrm{m}_{\text {prms }}$ & $\mathrm{kg}$ & 294 & 64 \\
\hline 21 & Machine mobile plate weight, $\mathrm{m}_{\text {prmr }}$ & $\mathrm{kg}$ & 64 & 64 \\
\hline 22 & Blowing agent part in product weight, - & & 0.05 & 0.05 \\
\hline 23 & Time of cycle, $\tau$ & $\mathrm{s}$ & 52 & 80 \\
\hline 24 & Surface of mold frame, $\mathrm{A}_{\mathrm{rf}}$ & $\mathrm{m}^{2}$ & 1.3 & 1.3 \\
\hline 25 & Surface of machine frame, $A_{\mathrm{rm}}$ & $\mathrm{m}^{2}$ & 1.73 & 1.73 \\
\hline 26 & Surface of machine plate, $A_{p m}$ & $\mathrm{~m}^{2}$ & 1.23 & 1.23 \\
\hline 27 & Surface of mold plate, $A_{p f}$ & $\mathrm{~m}^{2}$ & 0.63 & 0.63 \\
\hline 28 & Temperature of delivered steam, $t_{\text {pary }}$ & ${ }^{\circ} \mathrm{C}$ & 125 & 125 \\
\hline 29 & Temperature of mold, $t_{\mathrm{f}}$ & ${ }^{\circ} \mathrm{C}$ & 95.5 & 95.5 \\
\hline 30 & Temperature of frame mold surface, $t_{\text {powrf }}$ & ${ }^{\circ} \mathrm{C}$ & 90.8 & 52 \\
\hline 31 & Temperature of machine mold surface, $\mathrm{t}_{\text {powrm }}$ & ${ }^{\circ} \mathrm{C}$ & 49.8 & 41.6 \\
\hline 32 & Temperature of machine plate surface, $\mathrm{t}_{\mathrm{powpm}}$ & ${ }^{\circ} \mathrm{C}$ & 93.7 & 65 \\
\hline 33 & Temperature of mold plate surface, $t_{\text {powpf }}$ & ${ }^{\circ} \mathrm{C}$ & 93.6 & 73 \\
\hline 34 & Temperature of raw material, $\mathrm{t}_{\mathrm{o}}$ & ${ }^{\circ} \mathrm{C}$ & 26 & 26 \\
\hline 35 & Temperature of product removed from the mold, $t_{w}$ & ${ }^{\circ} \mathrm{C}$ & 87 & 87 \\
\hline 36 & Increase of mold temperature, $t_{\mathrm{fk}}-\mathrm{t}_{\mathrm{fp}}$ & ${ }^{\circ} \mathrm{C}$ & 16 & 9 \\
\hline 37 & Temperature rise of the mold frame, $\mathrm{t}_{\mathrm{rfk}}-\mathrm{t}_{\mathrm{rfp}}$ & ${ }^{\circ} \mathrm{C}$ & 3.3 & 5.1 \\
\hline 38 & Temperature rise of the machine frame, $t_{r m k}-t_{r m p}$ & ${ }^{\circ} \mathrm{C}$ & 2.9 & 2.8 \\
\hline 39 & Temperature rise of the machine plate, $t_{p m s k}-t_{p m s p}$ & ${ }^{\circ} \mathrm{C}$ & 2.4 & 2.6 \\
\hline 40 & Temperature rise of the mobile plate, $t_{\text {prmrk }}-t_{\text {prmrp }}$ & ${ }^{\circ} \mathrm{C}$ & 4.7 & 2.5 \\
\hline 41 & Mold temperature decrease during cooling, $t_{\text {fchp }}-t_{\text {ochk }}$ & ${ }^{\circ} \mathrm{C}$ & 18.9 & 18.9 \\
\hline 42 & Product temperature decrease during cooling, $\mathrm{t}_{\mathrm{wp}}-\mathrm{t}_{\mathrm{wk}}$ & ${ }^{\circ} \mathrm{C}$ & 42 & 42 \\
\hline
\end{tabular}


Table 2.

Calculation formulas of balance heat components

Calculation formulas

\begin{tabular}{|c|c|}
\hline 1 & $\mathrm{Q}_{\mathrm{d}}=\mathrm{m}_{\mathrm{z}} \mathrm{h}+\mathrm{p}_{2} \mathrm{~V}_{1}$ \\
\hline & $\mathrm{Q}_{\mathrm{fo}}=\left(\mathrm{m}_{\mathrm{fs}}+\mathrm{m}_{\mathrm{fr}}\right) \mathrm{c}_{\mathrm{f}}\left(\mathrm{t}_{\mathrm{fk}}-\mathrm{t}_{\mathrm{fp}}\right)+\left(\mathrm{m}_{\mathrm{rfs}}+\mathrm{m}_{\mathrm{rfr}}\right) \mathrm{c}_{\mathrm{rf}}\left(\mathrm{t}_{\mathrm{rfk}}-\mathrm{t}_{\mathrm{rfp}}\right)+\left(\mathrm{m}_{\mathrm{rms}}+\mathrm{m}_{\mathrm{rmr}}\right) \mathrm{c}_{\mathrm{rm}}\left(\mathrm{t}_{\mathrm{rmk}}-\mathrm{t}_{\mathrm{rmp}}\right)$ \\
\hline 2 & $+m_{\text {prms }} c_{p r m s}\left(t_{p m s k}-t_{p m s p}\right)+m_{p r m r} c_{p r m r}\left(t_{p r m r k}-t_{p r m r p}\right)$ \\
\hline 3 & $\mathrm{Q}_{\mathrm{w}}=\mathrm{m}_{\mathrm{w}}\left[0,05 \mathrm{c}_{\mathrm{par} \text { porof }}+\mathrm{c}_{\mathrm{ps}}\left(\mathrm{t}_{\mathrm{w}}-\mathrm{t}_{\mathrm{o}}\right)\right]$ \\
\hline 4 & $\mathrm{Q}_{\mathrm{ch}}=\mathrm{m}_{\mathrm{f}} \mathrm{c}_{\mathrm{f}}\left(\mathrm{t}_{\mathrm{fchp}}-\mathrm{t}_{\mathrm{ochk}}\right)+\mathrm{m}_{\mathrm{w}} \mathrm{c}_{\mathrm{ps}}\left(\mathrm{t}_{\mathrm{pp}}-\mathrm{t}_{\mathrm{pk}}\right)$ \\
\hline 5 & $\mathrm{Q}_{\mathrm{k}}=\left(\mathrm{m}_{\mathrm{wk}}+\mathrm{m}_{\mathrm{wps}}\right) \mathrm{c}_{\mathrm{w}}\left(\mathrm{t}_{\mathrm{w}}-\mathrm{t}_{\mathrm{o}}\right)$ \\
\hline 6 & $\mathrm{Q}_{\text {konw }}=\alpha \tau_{\mathrm{c}}\left[\left(\mathrm{t}_{\text {powrf }}-\mathrm{t}_{\mathrm{ot}}\right) \mathrm{A}_{\mathrm{rf}}+\left(\mathrm{t}_{\text {powrm }}-\mathrm{t}_{\mathrm{ot}}\right) \mathrm{A}_{\mathrm{rm}}+\left(\mathrm{t}_{\text {powpm }}-\mathrm{t}_{\mathrm{ot}}\right) \mathrm{A}_{\mathrm{pm}}+\left(\mathrm{t}_{\mathrm{powpf}}-\mathrm{t}_{\mathrm{ot}}\right) \mathrm{A}_{\mathrm{pf}}\right]$ \\
\hline 7 & $\mathrm{Q}_{\text {prom }}=\mathrm{C}_{0}\left\{\varepsilon_{\mathrm{Al}}\left[\mathrm{A}_{\mathrm{rf}}\left(\mathrm{T}_{\mathrm{rfk}}\right)^{4}+\mathrm{A}_{\mathrm{pfr}}\left(\mathrm{T}_{\mathrm{prmrk}}\right)^{4}\right]+\varepsilon_{\mathrm{m}}\left[\mathrm{A}_{\mathrm{rm}}\left(\mathrm{T}_{\mathrm{rmk}}\right)^{4}+\mathrm{A}_{\mathrm{pm}}\left(\mathrm{T}_{\mathrm{pmsk}}\right)^{4}\right]\right\}$ \\
\hline 8 & $Q_{s t}=Q_{d}-Q_{f o}-Q_{w}-Q_{c h}-Q_{k}-Q_{k o n w}-Q_{\text {prom }}$ \\
\hline 0 & $\mathrm{Q}_{\text {rozr }}=\left(\mathrm{m}_{\mathrm{fs}}+\mathrm{m}_{\mathrm{fr}}\right) \mathrm{c}_{\mathrm{f}}\left(\mathrm{t}_{\mathrm{fk}}-\mathrm{t}_{\mathrm{tot}}\right)+\left(\mathrm{m}_{\mathrm{rfs}}+\mathrm{m}_{\mathrm{rfr}}\right) \mathrm{c}_{\mathrm{rf}}\left(\mathrm{t}_{\mathrm{rfk}}-\mathrm{t}_{\mathrm{ot}}\right)+\left(\mathrm{m}_{\mathrm{rms}}+\mathrm{m}_{\mathrm{rmr}}\right) \mathrm{c}_{\mathrm{rm}}\left(\mathrm{t}_{\mathrm{rmk}}-\mathrm{t}_{\mathrm{ot}}\right)$ \\
\hline & $+\mathrm{m}_{\text {prms }} c_{\text {prms }}\left(t_{\text {rmk }}-t_{o t}\right)+m_{\text {prmr }} c_{\text {prmr }}\left(t_{\text {prmrk }}-t_{o t}\right)$ \\
\hline
\end{tabular}

Table 3.

Results of calculation of balance heat components

\begin{tabular}{ccccc}
\hline & Component & Unit. & Machine No. 1 & Machine No. 2 \\
\hline 1 & $\mathrm{Q}_{\mathrm{d}}$ & $\mathrm{kJ}$ & 6943.585 & 5552.085 \\
\hline 2 & $\mathrm{Q}_{\mathrm{fo}}$ & $\mathrm{kJ}$ & 3102.813 & 2108.743 \\
\hline 3 & $\mathrm{Q}_{\mathrm{w}}$ & $\mathrm{kJ}$ & 605.118 & 471.787 \\
\hline 4 & $\mathrm{Q}_{\mathrm{ch}}$ & $\mathrm{kJ}$ & 2290.239 & 2282.049 \\
\hline 5 & $\mathrm{Q}_{\mathrm{k}}$ & $\mathrm{kJ}$ & 196.293 & 195.782 \\
\hline 6 & $\mathrm{Q}_{\text {konw }}$ & $\mathrm{kJ}$ & 391.986 & 332.083 \\
\hline 7 & $\mathrm{Q}_{\text {prom }}$ & $\mathrm{kJ}$ & 3.468 & 2.645 \\
\hline 8 & $\mathrm{Q}_{\text {st }}$ & $\mathrm{kJ}$ & 353.668 & 158.996 \\
\hline 9 & $\mathrm{Q}_{\text {rozr }}$ & $\mathrm{kJ}$ & 30027.459 & 17188.171 \\
\hline
\end{tabular}

a)

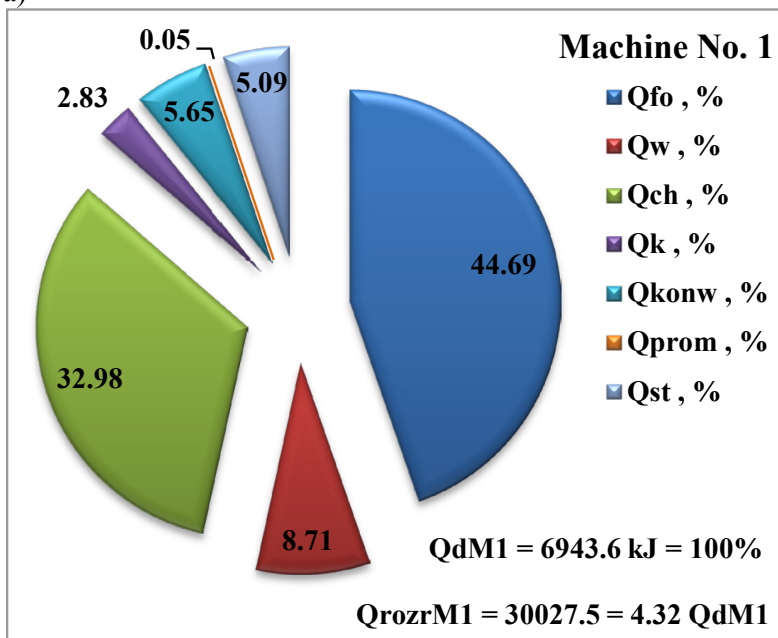

b)

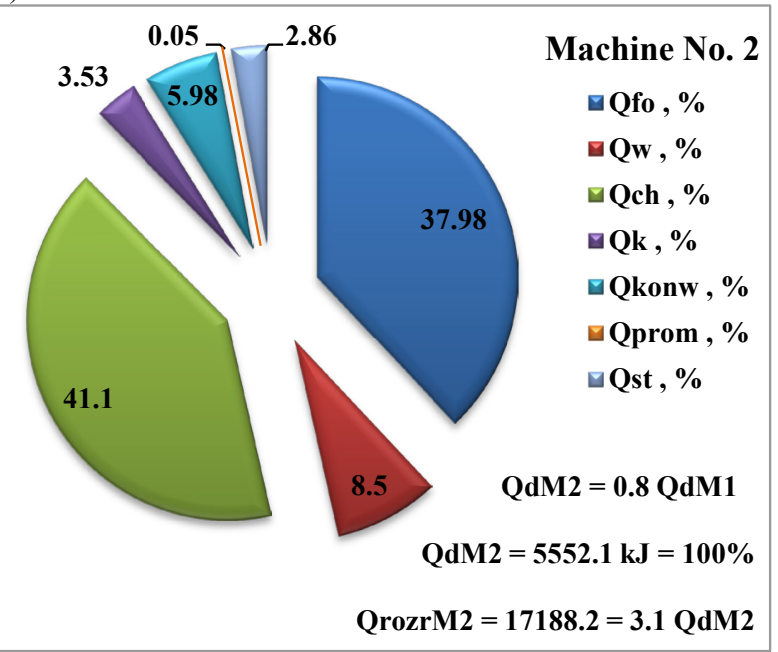

Fig. 7. Comparison of heat balance percentage components of mold equipment for machine: a) - No. 1, b) - No. 2

The heat balance shows that the largest part of the heat input is consumed for cyclic heating of molds equipment and heat received from the mold during the cooling spray of water. These components are about 5 times greater than the heat absorbed by the material during processing, and removed together with the product $\mathrm{Q}_{\mathrm{w}}$.
A comparison of the percentage of heat balance that mold equipment machine No. 2 is characterized by a reduced part of heat cyclic heating of instrumentation elements $Q_{f o}$ and twice lower rate of heat loss $\mathrm{Q}_{\mathrm{st}}$ caused by a temperature stability of mold, venting and leakage mold tooling. 


\section{Conclusions}

The main conclusions of the work are as follows:

- modernization of mold equipment in the machine No. 2 decreased about $20 \%$ the heat energy requirement during the production cycle, and 2-times reduced heat losses caused by the mold temperature stability and leaking equipment,

- the largest part of the heat input is consumed in the molds for cyclic heating of equipment and it is five times greater than the heat absorbed by the material processed and removed together with the product from the mold,

- heat energy consumed during machine startup is about four times greater than the heat demand in the production cycle.

\section{Acknowledgements}

The work was made as a part of the research order No. 5/20132 the Schaumaplast-Organika Sp. $\quad \mathrm{z}$ o.o. "Development and implementation in the enterprise Schaumaplast-Organika Sp. $\mathrm{z}$ o.o. the energy-efficient and optimized method of producing elements from expanded polystyrene".

\section{References}

[1] Pacyniak, T. \& Kaczorowski, R. (2010). Investigations of polystyrene pre-expansion process by use of the test stand equipped with batch pre-expander. Archives of Metallurgy and Materials. 55(3), 883-888.

[2] Pacyniak, T., Buczkowska, K. \& Bogus, W. (2012). The analysis of the influence of the polystyrene patterns shaping parameters on the resistance properties. Archives of Foundry Engineering. 12(2), 227-234.

[3] Wiśniewski, S. (1994). Heat transfer. Warszawa: PWN.

[4] Wiśniewski, S. (1999). Technical thermodynamics. Warszawa: WNT.

[5] Wukałowicz, M. P. (2005). Graph of enthalpy - entropy of steam up to $1000^{\circ} \mathrm{C}$ and $95 \mathrm{MPa}$. Warszawa: WNT. 